\title{
THE EFFECT OF HEALTH INFRASTRUCTURE DEVELOPMENT, EDUCATION, AND THE NUMBER OF POPULATIONS ON ECONOMIC GROWTH IN NORTH SUMATERA PROVINCE
}

\author{
Mariyatul Kubtiyah Ritonga ${ }^{1 *}$, Anhar Fauzan Priyonob ${ }^{2}$ \\ 1*) Postgraduate Program, Universitas Negeri Medan \\ ${ }^{2}$ Faculty of Economics and Business, Universitas Padjadjaran \\ Email: mariyatulkubtiyah@gmail.com
}

\begin{abstract}
Economic Growth in North Sumatera priod 2000 until 2012 shows the condition that increases continuously, but the increase did not have an impact on education, health. This study aimed to analyze the influence of the health infrastructure, education infrastructure and population to economic growth in the province of North Sumatra simultaneously and partially. The data used are secondary data from BPS in North Sumatra time series from 2000 till 2012. Data analysis was performed by using OLS (Ordinary Least Square) with a multiple linear regression models estimated with the help of the program Eviews 7. The results of this study showed that simultaneous variable health infrastructure, education infrastructure and population have a significant effect on economic growth in the province North Sumatra. While partially concluded that variable infrastructure and population health positive and significant effect; educational infrastructure but not significant positive effect on economic growth in the province of North Sumatra. The results of this study also showed that the most dominant variables to economic growth in the province of North Sumatra is the total population.
\end{abstract}

Key words: Infrastructure, Education, Health, Population and Economic Growth

\section{INTRODUCTION}

1 nfrastructure development in North Sumatera Province has not been fully realized to meet community needs, such as infrastructure development in the health and education sectors in line with the increasing population in North Sumatera Province. Because so far the government of North Sumatera Province has only focused on repairing and allocating APBD funds for road infrastructure, bridges, clean water, and others. However, he still lacks attention on infrastructure issues for the health and education sectors.

Economic growth has become the way of life for the nation of each country. The government can fall or stand strong depending on the low or high level of economic growth of the country (Todaro, 2006: 163). The following is the rate of economic growth proxied by GRDP in North Sumatra Province:

Table 1: Economic Growth Rate of North Sumatera Province

\begin{tabular}{|c|c|c|}
\hline \multicolumn{1}{|c|}{ Year } & \multicolumn{1}{|c|}{ PDRB } & Percentage \\
\hline 2000 & 69.154 .112 .380 .909 & - \\
\hline
\end{tabular}

QE Journal | Vol.08 - No.02 - 16 


\begin{tabular}{|l|l|l|}
2001 & 79.331 .335 .138 .970 & 14,72 \\
\hline 2002 & 89.670 .147 .516 .830 & 13,03 \\
\hline 2003 & 103.401 .370 .462 .659 & 15,31 \\
\hline 2004 & 118.100 .511 .824 .959 & 14,22 \\
\hline 2005 & 139.618 .313 .637 .245 & 18,22 \\
\hline 2006 & 160.376 .799 .093 .764 & 14,87 \\
\hline 2007 & 181.819 .737 .320 .359 & 13,37 \\
\hline 2008 & 213.931 .696 .775 .023 & 17,66 \\
\hline 2009 & 236.353 .615 .827 .920 & 10,48 \\
\hline 2010 & 275.056 .510 .000 .000 & 16,37 \\
\hline 2011 & 314.372 .440 .000 .000 & 14,29 \\
\hline 2012 & 351.118 .160 .000 .000 & 11,69 \\
\hline
\end{tabular}

Source: BPS North Sumatera Province

During the 2000 to 2012 observation years, the amount of economic growth proxied in the GRDP value that occurred in North Sumatra Province tended to increase from year to year. The highest GRDP amount occurred in 2012, namely 351,118.16 billion. Meanwhile, the lowest GRDP occurred in 2000, namely 69,154.11 billion. Furthermore, the highest increase in the percentage of GRDP occurred in 2005 amounting to 18.22 percent from the previous year (2004) to $139,618.31$ billion or an increase of 21,517.8 billion. Meanwhile, the lowest increase in the percentage of GRDP occurred in 2009 amounting to 10.48 percent or an increase of $22,421.91$ billion from the previous year (2008).

The increase in PDRB of North Sumatera Province every year shows an increase in the per capita income of the people of North Sumatera Province every year. Ironically, the increase in income per capita is not in line with the decline in poverty. This shows that there has been a fairly large income gap in North Sumatera Province. This gap is actually the government's failure to reduce the existing poverty rate. This can be seen from the development of the number of poor people in North Sumatera Province as follows:

Table 2: Total Poor Population in North Sumatera Province

\begin{tabular}{|l|l|l|}
\hline \multicolumn{1}{|c|}{ Year } & \multicolumn{1}{|c|}{ Total (000 Person) } & \multicolumn{1}{c|}{ Percentage } \\
\hline 2003 & 1889,4 & 15,89 \\
\hline 2004 & 1800,1 & 14,93 \\
\hline 2005 & 1840,2 & 14,68 \\
\hline 2006 & 1979,7 & 15,66 \\
\hline 2007 & 1768,4 & 13,9 \\
\hline 2008 & 1613,8 & 12,55 \\
\hline 2009 & 1499,7 & 11,51 \\
\hline 2010 & 1490,9 & 11,31 \\
\hline 2011 & 1407,2 & 11,33 \\
\hline 2012 & 1421,4 & 10,75 \\
\hline
\end{tabular}

Source: BPS North Sumatera Province 
One of the efforts to reduce the poverty rate is by increasing economic growth and the number of existing jobs. To increase GRDP, it should be supported by good educational infrastructure, health infrastructure and work productivity of the population of Prov North Sumatera Province.

Education infrastructure, health infrastructure and population are considered to have a role in the development of GRDP in North Sumatera Province. This is considered influential because in order to get a GRDP that is growing and increasing continuously, it must be supported by a good level of intellectual quality in a healthy community and supported by easy and adequate health services. Of course, this contribution will be more optimal if maximized by a large quantity of productive society. Of course this is expected to be in line with the increase in GRDP in North Sumatera Province.

Ideally, the increase in GRDP and population each year is in line with the development of infrastructure both in the health and education sectors in North Sumatera Province. This is because in order to advance a region, it is necessary to develop the human being itself through proper and adequate education services and be carried out with a healthy mind and body. It is hoped that through health and education services it can create an increase in human resources that are healthy, smarter and more productive. The development of education and health infrastructure, as well as the development of the population in North Sumaera Province are as follows

Table 3: The Development of Education Infrastructure, Health Infrastructure and Total of Populationa Years 2000 to 2012

\begin{tabular}{|c|c|c|c|c|c|c|c|c|c|}
\hline \multirow[b]{2}{*}{$\begin{array}{l}\text { Ye } \\
\text { ar }\end{array}$} & \multicolumn{4}{|c|}{ Educational Infrastructure } & \multirow[b]{2}{*}{$\begin{array}{l}\text { Tot } \\
\text { al }\end{array}$} & \multicolumn{2}{|c|}{ Health Infrastructure } & \multirow[b]{2}{*}{$\begin{array}{c}\text { Tot } \\
\text { al }\end{array}$} & \multirow[b]{2}{*}{$\begin{array}{c}\text { Total of } \\
\text { Populati-on }\end{array}$} \\
\hline & $\begin{array}{l}\text { Elementary } \\
\text { School }\end{array}$ & $\begin{array}{l}\text { Junior High } \\
\text { School }\end{array}$ & $\begin{array}{l}\text { Senior High } \\
\text { School }\end{array}$ & $\begin{array}{l}\text { Vocational } \\
\text { High School }\end{array}$ & & $\begin{array}{l}\text { Hos- } \\
\text { pital }\end{array}$ & $\begin{array}{l}\text { Public health } \\
\text { center }\end{array}$ & & \\
\hline $\begin{array}{l}20 \\
00\end{array}$ & 9.519 & 1.705 & 624 & 489 & $\begin{array}{l}12.3 \\
37\end{array}$ & 26 & 19.067 & $\begin{array}{l}19.0 \\
93\end{array}$ & 11.513 .973 \\
\hline $\begin{array}{l}20 \\
01\end{array}$ & 9.714 & 1.836 & 1.309 & 489 & $\begin{array}{l}13.3 \\
48\end{array}$ & 30 & 20.039 & $\begin{array}{l}20.0 \\
69\end{array}$ & 11.722 .397 \\
\hline $\begin{array}{l}20 \\
02 \\
\end{array}$ & 9.343 & 1.699 & 665 & 532 & $\begin{array}{l}12.2 \\
39 \\
\end{array}$ & 30 & 19.935 & $\begin{array}{l}19.9 \\
65 \\
\end{array}$ & 11.847 .075 \\
\hline $\begin{array}{l}20 \\
03\end{array}$ & 9.309 & 1.775 & 803 & 564 & $\begin{array}{l}12.4 \\
51\end{array}$ & 32 & 19.634 & $\begin{array}{l}19.6 \\
66 \\
\end{array}$ & 11.890 .399 \\
\hline $\begin{array}{l}20 \\
04\end{array}$ & 9.436 & 1.876 & 843 & 575 & $\begin{array}{l}12.7 \\
30 \\
\end{array}$ & 34 & 17.628 & $\begin{array}{l}17.6 \\
62 \\
\end{array}$ & 12.123 .360 \\
\hline $\begin{array}{l}20 \\
05\end{array}$ & 9.594 & 1.818 & 784 & 585 & $\begin{array}{l}12.7 \\
81\end{array}$ & 29 & 15.742 & $\begin{array}{l}15.7 \\
71 \\
\end{array}$ & 12.326 .678 \\
\hline $\begin{array}{l}20 \\
06\end{array}$ & 9.691 & 1.844 & 1.237 & 569 & $\begin{array}{l}13.3 \\
41\end{array}$ & 29 & 15.978 & $\begin{array}{l}16.0 \\
07\end{array}$ & 12.643 .494 \\
\hline $\begin{array}{l}20 \\
07\end{array}$ & 9.274 & 1.975 & 857 & 601 & $\begin{array}{l}12.7 \\
07\end{array}$ & 57 & 18.003 & $\begin{array}{l}18.0 \\
60\end{array}$ & 12.834 .371 \\
\hline $\begin{array}{l}20 \\
08\end{array}$ & 10.277 & 1.996 & 717 & 704 & $\begin{array}{l}13.6 \\
94\end{array}$ & 62 & 18.101 & $\begin{array}{l}18.1 \\
63\end{array}$ & 13.042 .317 \\
\hline $\begin{array}{l}20 \\
09\end{array}$ & 7.446 & 1.562 & 928 & 704 & $\begin{array}{l}10.6 \\
40 \\
\end{array}$ & 59 & 18.161 & $\begin{array}{l}18.2 \\
20\end{array}$ & 13.248 .386 \\
\hline $\begin{array}{l}20 \\
10\end{array}$ & 7.427 & 1.888 & 912 & 479 & $\begin{array}{l}10.7 \\
06\end{array}$ & 44 & 21.155 & $\begin{array}{l}21.1 \\
99\end{array}$ & 12.982 .204 \\
\hline $\begin{array}{l}20 \\
11 \\
\end{array}$ & 11.693 & 3.201 & 1.402 & 834 & $\begin{array}{l}17.1 \\
30 \\
\end{array}$ & 44 & 20.881 & $\begin{array}{l}20.9 \\
25 \\
\end{array}$ & 13.103 .596 \\
\hline $\begin{array}{l}20 \\
12 \\
\end{array}$ & 9.467 & 2.584 & 1.100 & 755 & $\begin{array}{l}13.9 \\
06\end{array}$ & 61 & 22.168 & $\begin{array}{l}22.2 \\
29\end{array}$ & 13.215 .401 \\
\hline
\end{tabular}

Source: BPS North Sumatra Province 
Based on the table above, the amount of education infrastructure and health infrastructure tends to fluctuate from year to year. Meanwhile, the population growth tends to be stable and increases from year to year. For more details, the development of the number of education infrastructure in North Sumatera Province can be seen from the following figure:

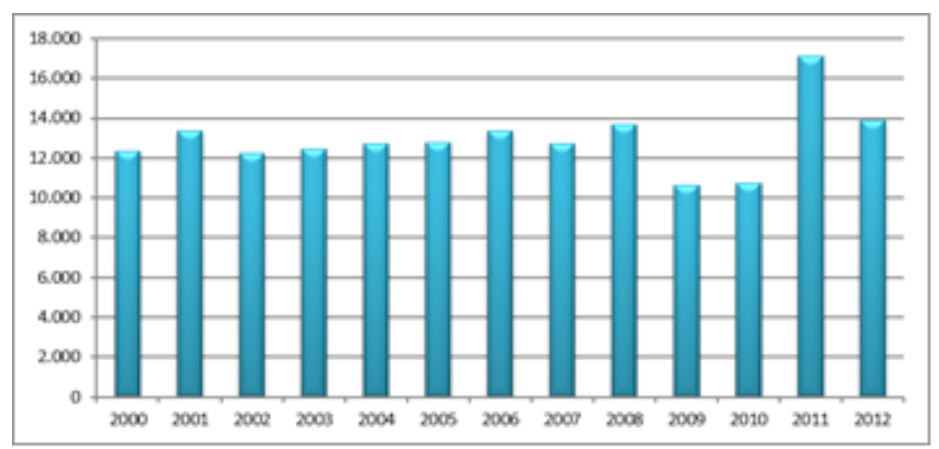

Figure 1: The Amount of Education Infrastructure in North Sumatera Province 2000 to 2012

Source: Processed data (BPS North Sumatera Province)

Based on Table 1 and Figure 1 above, it can be seen that the highest amount of education infrastructure occurred in 2011, namely 17,130 schools. Meanwhile, the lowest education infrastructure occurred in 2009, namely 10,706 schools. Infrastructure in the education sector is seen through the number of schools for Elementary Schools, Junior High Schools, and Senior High School and the equivalent. If it is related to economic growth in the Province of North Sumaetra, it is known that ideally the increasing economic growth in a region is in line with the improvement of the education infrastructure in that area. However, it turns out that not all increases in economic growth are followed by increases in the amount of educational infrastructure. This can be clearly observed, for example in 2009, the increase in GRDP in that year by 10.48 percent turned out to be inversely proportional to the decrease in the amount of education infrastructure by 22.3 percent. This indicates a mismatch between the amount of GRDP and the amount of education infrastructure in North Sumaetra Province.

Seeing this phenomenon, the government of North Sumatera Province must be able to overcome the problems of infrastructure development in the health and education sectors in order to achieve the development of quality human resources, which are the main points in the development and future growth of the Indonesian economy. Not only adding infrastructure which is a plan that must be carried out by the government, but also building quality, feasibility, maintenance and repair of existing infrastructure to increase economic growth in each region for short-term plans and increase community welfare to reduce disparities between regions. become a long term priority. Not only that, the increase in population every year is actually a real threat if the government does not increase the number of education and public health infrastructure in a balanced manner. This could result in many future generations who are less intelligent 
and less healthy due to the high cost of health and education in this province, which has an impact on the long-term economic growth of the community.

\section{RESEARCH METHOD}

The model specification used is adapted from several previous studies by making adjustments that are considered to provide better results to explain the factors that influence economic growth in North Sumatera Province from 2000 to 2012 using multiple regression analysis with the method Ordinary Least Square (OLS). For this reason, the functions used in this study are:

So the models in this study are:

$$
E G=f(E I, H I, T P)
$$

From equation 1 , then it is specified into the logarithmic form of the model as follows:

$$
\log E G=\beta 0+\beta 1 \operatorname{LogEI}+\beta 2 \log H I+\beta 3 \log P P+e
$$

Where :

$\mathrm{EG}=$ Economic Growth (GRDP)

$\mathrm{EI}=$ Educational Infrastructure

$\mathrm{HI}=$ Health Infrastructure

TP $=$ total population

Bo $=$ Constant

$\beta 1-\beta 3=$ Regression coefficient

Log = Logarithm

e $=$ Error Term

In this study, the research model is transformed into a logarithmic form. This is because there are differences in the units and quantities of the independent variables, so the regression equation must be made using a natural logarithmic model. The reasons for choosing Gujarati's (2006) natural logarithmic model are as follows:

1. Avoid heteroscedasticity.

2. Knowing the coefficient that shows elasticity.

3. Bring the data scale closer.

In this research, it is aimed to see the effect of health infrastructure, education infrastructure and population on economic growth in North Sumatera Province. The data needed in this research is secondary data. And for secondary data in this study used data from BPS (Central Statistics Agency) North Sumatera Province. In this study, the data used were from 2000 to 2012 with a sample size of 13 years.

\section{RESULT AND DISCUSSION}

\section{Overall Parameter Test (F-test)}

Simultaneously the three independent variables showed a high enough F-Stat value, namely 95.77 with prob. amounting to 0,000 , so $\mathrm{Ha}$ is rejected, which means that 
together changes in the variables of health infrastructure, education infrastructure and population have a significant effect on economic growth in North Sumatra Province.

\section{Partial Test (t-test)}

The $t$ test (partial) in this study was conducted to determine whether there was a significant influence on the variables of health infrastructure, education infrastructure and population size on economic growth in North Sumatra Province. The results of the calculation of the partial test are as follows:

Table 4: Hypothesis Test Results

\begin{tabular}{lllll}
\hline \hline Variable & Coefficient & Std. Error & t-Statistic & Prob. \\
\hline \hline C & -143.4382 & 10.39927 & -13.79309 & 0.0000 \\
LOG(HEALTH) & 0.801796 & 0.305274 & 2.626479 & 0.0275 \\
LOG(EDUCATION) & 0.316557 & 0.265461 & 1.192480 & 0.2636 \\
LOG(POPULATION) & 10.11258 & 0.628236 & 16.09679 & 0.0000 \\
\hline \hline R-squared & 0.969629 & Mean dependent var & 32.69220 \\
Adjusted R-squared & 0.959506 & S.D. dependent var & 0.536212 \\
S.E. of regression & 0.107903 & Akaike info criterion & -1.367511 \\
Sum squared resid & 0.104787 & Schwarz criterion & -1.193681 \\
Log likelihood & 12.88882 & Hannan-Quinn criter. & -1.403241 \\
F-statistic & 95.77948 & Durbin-Watson stat & 1.280389 \\
Prob(F-statistic) & 0.000000 & & \\
\hline \hline
\end{tabular}

Source: Research data (processed)

Based on the table above, the following conclusions can be obtained:

1. The health infrastructure variable has a positive and significant effect on the economic growth of North Sumatera Province with a Prob value. of 0.0275 or significant at the 5 percent alpha level.

2. The education infrastructure variable has a positive effect on the economic growth of North Sumatera Province.

3. The population variable has a positive and significant effect on the economic growth of North Sumatera Province with a Prob value. equal to 0.000 or significant at the alpha level of 1 percent.

Coefficient Value

The coefficient value is able to show the proportion of changes in the amount of economic growth in North Sumatera Province in one unit for each variable. The coefficient of each variable is based on the research results as shown in the following model:

$$
\log (P E)=-143.4382+0.8017 \log (I K)+0.3165 \log (I P)+10.1125 \log (J P)
$$

Based on the coefficient above, it can be explained as follows:

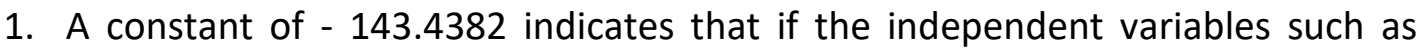
health infrastructure, education infrastructure and population are constant, QE Journal |Vol.08 - No.02 - 21 
then the economic growth of North Sumatera Province will decrease by 143.4382 percent.

2. Every increase in health infrastructure by 1 percent will increase the economic growth of North Sumatra Province by 0.8017 percent.

3. Every increase in education infrastructure by 1 percent, it will increase the economic growth of North Sumaetra Province by 0.3165 percent.

Each 1 percent increase in population will increase the economic growth of North Sumatera Province by 10.1125 percent.

\section{Variable Number of Educational Infrastructure on Economic Growth in North Sumatera Province}

The variable amount of education infrastructure has a positive but insignificant relationship to economic growth in North Sumatera Province. There are several things that are thought to have contributed to the insignificance of the amount of education infrastructure on economic growth in North Sumatera Province, namely the first is the quality of education that is less relevant to the needs of the world work market and does not produce workers with an entrepreneurial mentality; secondly, graduates of education or labor force have not yet matched the vacancies or jobs in North Sumatera, which has resulted in many unemployment; third, many qualified workers who are accepted work outside the city or abroad; and the last one is the large number of high school graduates and their equivalent who do not continue to the tertiary level due to several things, namely the lack of willingness and the high cost of education in tertiary institutions. Furthermore, the results of this study are also in line with Yanuar's (2006) previous research. The relationship between infrastructure development and output growth and its impact on inequality in Indonesia (panel data for 26 provinces). The results of this study indicate that educational infrastructure affects the total output of all sectors in Indonesia. It is understandable that the increasing number of schools is expected to be in line with the increasing equity and learning opportunities for the community. This is of course expected to increase the economic growth of an area because it is hoped that the more people who get education, the more likely people will work and contribute to the GRDP in an area.

Therefore, the results of this study indicate that the greater the number of educational infrastructure, there is a trend in line with the greater economic growth in North Sumatera Province.

\section{Variable Number of Health Infrastructure on Economic Growth in North Sumatra Province}

The variable number of health infrastructure has a positive and significant relationship to economic growth in North Sumatera Province at the alpha level of 5 percent. This is in accordance with the initial hypothesis of the study. The increase in the amount of economic growth in North Sumatera Province occurred due to changes in the amount of health infrastructure. The results of this study reveal that every 1 percent increase in the amount of health infrastructure will increase the amount of economic growth in 
North Sumatera Province by 0.3165 percent. Furthermore, the results of this study are also in line with Yanuar's (2006) previous research. The relationship between infrastructure development and output growth and its impact on inequality in Indonesia (panel data for 26 provinces). The results of this study indicate that health infrastructure affects the total output of all sectors in Indonesia. It is understandable that the increasing number of health infrastructure is expected to be in line with the increasing number of health services in the community. This, of course, is expected to indirectly increase the economic growth of an area because it is expected that from more and more health infrastructure, there is a tendency for the greater the possibility of people getting health facilities coupled with the increasing number of health insurance that is more affordable to the public such as BPJS, so that people are healthier. and is expected to be able to continue to work and contribute to GRDP in North Sumatera.

Therefore, the results of this study indicate that the greater the number of health infrastructure, there is a trend in line with the greater economic growth in North Sumatera Province.

\section{Variable Number of Population on Economic Growth in North Sumatera Province}

The population variable has a positive and significant relationship to economic growth in North Sumatera Province at the alpha level of 1 percent. This is in accordance with the initial hypothesis of the study. The increase in the amount of economic growth in North Sumatera Province occurred due to changes in population. The results of this study reveal that every 1 percent increase in population will increase the amount of economic growth in North Sumatra Province by 10.112 percent. This shows that the development of the population each year is in line with the amount of economic growth in North Sumatera Province each year. This can be understood, the large population in North Sumatera Province will be in line with the large number of working people so that it can contribute to economic growth in the region. In addition, the large population in Sumatra Province is a strategic potential market share in developing innovative products to be produced in order to meet the needs of the community.

Furthermore, it is known from the coefficient of the regression model equation in this study that the coefficient of the regression equation on the population variable is the largest, which is 10.112 . This means that the population size variable is the most dominant variable in this study which affects the amount of economic growth in North Sumatera Province. Therefore, the results of this study indicate that the greater the population, the greater the trend of economic growth in North Sumatra Province.

\section{Education Infrastructure, Health Infrastructure and Total Population Against Economic Growth in North Sumatera Province}

Simultaneously the three independent variables showed a high enough F-Stat value, namely 95.77 with prob. amounting to 0,000 , so $\mathrm{Ha}$ is rejected, which means that together changes in the variable number of health infrastructure, the number of education infrastructure and the number of population have a significant effect on the economic growth of North Sumatera Province. 
In addition, it turns out that the variables of the number of health infrastructure, the number of education infrastructure and the population are able to explain the economic growth model of North Sumatra Province of 96.96 percent. And the remaining 3.04 percent is influenced by other variables not examined in this study. This shows that the model formed in this study has been able to explain the economic growth of North Sumatera Province.

\section{CONCLUSIONS AND RECOMMENDATIONS}

\section{Conclusion}

1. Together, changes in health infrastructure, education infrastructure and population have a significant effect on the economic growth of North Sumatera Province.

2. Partially, the health infrastructure and population have a positive and significant effect; meanwhile, education infrastructure has a positive but not significant effect on economic growth in North Sumatera Province.

3. The variables of health infrastructure, education infrastructure and population are able to explain the economic growth model for North Sumatera Province 96.96 percent. And the remaining 3.04 percent is influenced by other variables not examined in this study.

\section{Suggestion}

1. The government should improve not only the quantity of education and health infrastructure but also the quality of services. In education infrastructure, it is hoped that adequate buildings and facilities will be created in accordance with the demands of the market and the world of education, while in terms of health infrastructure, it is hoped that standardized and equitable service quality can be created for patients of all economic levels so that the level of public trust in government health public services will be stronger and not. many patients who go far for treatment abroad, for example to Penang Malaysia.

2. There are limited time and data sources in this study, so it is hoped that in future studies more annual data will be used and can include more complex variables and can further analyze economic growth in North Sumatera Province such as road infrastructure.

3. The suggestions that can be given related to the research results are that it is still necessary to re-examine this research using a different approach method, as well as a different review concept so that comparative studies can be carried out and support new findings.

\section{REFERENCES}

Achmad Sjafii. 2009. Pengaruh Investasi Fisik dan investasi pembangunan manusia Terhadap pertumbuhan ekonomi. jawa timur 1990-2004. Fakultas Ekonomi Universitas Airlanga Surabaya. Jurnal (dipublikasikan melalui www.google.com).

Agus Widarjono. 2007. Ekonometrika Teori dan Aplikasi untuk Ekonomi dan Bisnis Ekonisia. Yogyakarta. 
Badan Pusat Statistik (BPS). Sumatera Utara Dalam Angka. Tahun 2008-2013

Bulohlabna, C. 2008. Tipologi dan Pengaruh Infrastruktur terhadap Pertumbuhan Ekonomi kawasan Timur Indonesia. Skripsi Fakultas Ekonomi dan Manajemen. Institut Pertanian Bogor, Bogor

Deddy Radiansyah. 2012. Analisis Kontribusi Infrastruktur terhadap Pertumbuhan Ekonomi Regional di Indonesia (Periode Tahun 1996 s.d. 2008). Fakultas Ekonomi Program Magister Perencanaan dan Kebijakan Publik Kekhususan Manajemen Sektor Universitas Indonesia. Tesis (dipublikasikan melalui www.google.com)

Gujarati, Damodar, N. 2006. Ekonomiterika Dasar. Jakarta : Erlangga.

Hanafie, R. 2010. Pengantar Ekonomi Pertanian. Penerbit Andl : Yogyakarta

Harahap, Abdul Halim. 2011. Pengaruh Program Pengembangan Infrastruktur Sosial Ekonomi Wilayah (Pisew) terhadap Pengembangan Wilayah Kabupaten Langkat. Sekolah Pasca Sarjana Universitas Sumatera Utara.

Kodoratie, R.J. 2003. Manajemen dan Rekayasa Infrastruktur. Pustaka Pelajar. Yogyakarta.

Mankiw, N.G. (2006). Pengantar Ekonomi Makro. Edsisi Tiga Jakarta : Salemba Empat.

Setiadi, Elen. (2006). Pengaruh Pembangunan Infrastruktur dasar terhadap Pertumbuhan Ekonomi Regional Indonesia (8 Propinsi di Sumatera) Jakarta : FE UI.

Sicat, G.P. dan Arndt, H.W. (1991). IImu Ekonomi untuk Konteks Indonesia. Jakarta: LP3ES

Setyaningrum, E. 1997. Analisis Pembiayaan Infrastruktur Perkotaan Studi Kasus Dati II Kabupaten Sleman DIY. Tesis Program Pasca Srjana Universitas Gajah Mada Yogyakarta.

Todaro, M.P. (1995). Ekonomi untuk Negara Berkembang : Suatu Pengantar tentang Prinsip-prinsip, masalah kebjakan pembangunan ; Penerjemah, Agustinus Subekti, Edisi 3, cetakan 1, Jakarta : Bumi Aksara.

Todaro. P. Michael dan Smith, C, Stephen. 2006. Pembangunan Ekonomi Edisi Sembilan Jilid I. Penerbit Erlangga. Jakarta.

Winarno, Wing Wahyu. 2007. Analisis Ekonometrika dan Statistika dengan Eviews. Yogyakarta : UPP STIM YKPN.

Yanuar, R. 2006 Kaitan Pembangunan Infrastuktur serta Dampaknya terhadap Kesenjangan di Indonesia. Tesis Magister Sains. Program Pasca Sarjana IPB. Bogor (dipublikasikan melalui www.google.com). 